\title{
EFFECT OF 90-DAY CONTINUOUS EXPOSURE TO METHYLISOBUTYLKETONE ON DOGS, MONKEYS AND RATS
}

J. D. MACEWEN

E. H. VERNOT

C. C. HAUN

SYSTEMED CORPORATION

JUNE 1971

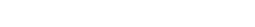

$\underbrace{4} 002 z$ - 00 in

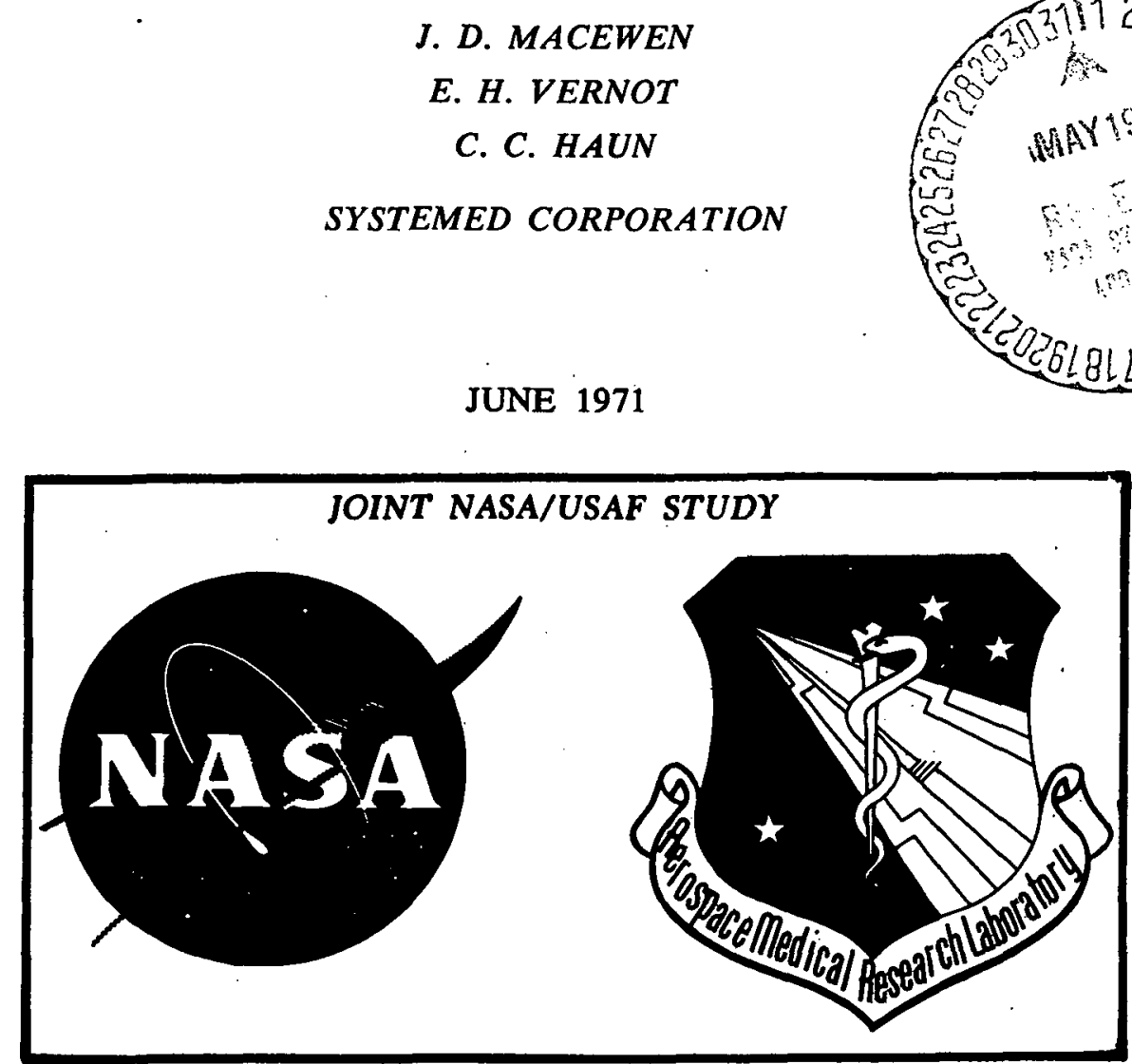

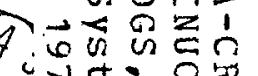
it 0 $\rightarrow i_{\pi}=1$ (1) $O$ $N$ D 2 w $\omega$ 两 00 过 C - एक zo 00

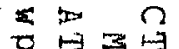

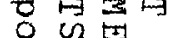

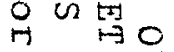

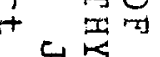
$\infty \stackrel{5}{0}$ (1) $\square+\cdots$ D) $\mathrm{U}_{\mathrm{i}} \mathrm{i}$ 000 $\Omega \rightarrow 00$

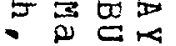

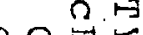
กी $\Omega \sim 0$ 至

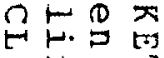
$\rightarrow H$ $0 \div 0 \stackrel{0}{2}$

Approved for public release; distribution unlimited. 



\section{DOCUMENT CONTROL DATA - R \& D}

(Security classification of title, body of abstract and indexing annolation must be entered when the overall report is classified)

1. ORIGINATING ACTIVITY (Corporate author)

SysteMed Corporation

Corporate Heâdquarters

Suite 472

4500 Campus Drive, Newport Beach, Calif. 92660

3. REPORT TITLE

EFFECT OF 90-DAY CONTINUOUS EXPOSURE TO

METHYLISOBUTYLKETONE ON DOGS, MONKEYS AND RATS

4. DESCRIPTIVE NOTES (TYPe of report and inclusive dates)

Final Report, June 1970 - September 1970

5. AU THOR(S) (First name, middlo initial, last namo)

J. D. MacEwen

E. H. Vernot

C. C. Haun

\begin{tabular}{|c|c|c|}
\hline $\begin{array}{l}\text { 6. REPORT DATE } \\
\text { June } 1971\end{array}$ & $\begin{array}{c}\text { 7a. TOTAL NO. OF PAGES } \\
23\end{array}$ & $\begin{array}{c}\text { 7b. NO. OF REFS } \\
4\end{array}$ \\
\hline $\begin{array}{l}\text { 8a. CONTRACT OR GRANTNO. F } 33615-70-\mathrm{C}-1046 \\
\text { b. PROJECT No. } 6302\end{array}$ & \multicolumn{2}{|c|}{$\begin{array}{l}\text { 9a. ORIGINATOR'S REPORT NUMBER(S) } \\
\text { SysteMed Corporation Report } \\
\text { Number } \mathrm{W}-71003\end{array}$} \\
\hline $\begin{array}{l}\text { c. Task No. } 630201 \\
\text { ๙. Work Unit No. } 630201008\end{array}$ & \multicolumn{2}{|c|}{$\begin{array}{l}\text { 9b. OTHER REPORT NO(S) (Any othet numbers that may be as signed } \\
\text { this report) } \\
\text { AMRL-TR }-71-65\end{array}$} \\
\hline
\end{tabular}

10. DISTRIBUTION STATEMENT

Approved for public release: distribution unlimited

\begin{tabular}{|l|l|}
\hline 11. SUPPLEMENTARY NOTES & $\begin{array}{l}\text { 2. SPONSORING MILITARY ACTIVITY Aerospace Medical } \\
\text { Research Laboratory, Aerospace Medical } \\
\text { Division, Air Force Systems Command, } \\
\text { Wright-Patterson AFB, OH 45433 }\end{array}$ \\
\hline
\end{tabular}

Continuous exposure of rats, dogs and monkeys to $410 \mathrm{mg} / \mathrm{M}^{3}$ methylisobutylketone vapor (MIBK) was conducted to evaluate the provisional spacecraft exposure limit of $20 \mathrm{ppm}$ established by the Space Science Board, NAS/NRC in 1968. The exposure conducted in a simulated space cabin environment did not produce any measurable changes in dogs or monkeys. Rats developed hyaline droplet nephrosis within 2 weeks of exposure which was reversible upon removal from the MIBK even after 90 days. The data obtained indicated that the 60-minute emergency exposure limit of $100 \mathrm{ppm}$ and the 90- and 1000-day provisional limits as established by the Space Science Board contain a wide margin of safety.

Key Words:

\author{
Methylisobutylketone \\ Toxicology \\ Space cabin limits
}

Dogs
Monkeys
Rats 


\section{FOREWORD}

This is one of a series of technical reports describing results of the experimental laboratory program being conducted in the Toxic Hazards Research Unit. This report is concerned with chronic inhalation toxicity of methylisobutylketone (MIBK), a solvent used in the manufacture of plastic and a common spacecraft contaminant. The research was sponsored by the National Aeronautics and Space Administration under Amendment No. 4 to NASA Purchase Request T-64130(G), funds applied to Air Force Contract F33615-70-C-1046. Work was performed by SysteMed Corporation personnel located at Wright-Patterson Air Force Base. K. C. Back, PhD, Chief of the Toxicology Branch, was the technical contract monitor for the Aerospace Medical Research Laboratory.

J. D. MacEwen, PhD, was the principal investigator for the SysteMed Corporation. Acknowledgement is made to P. M. Chikos, Capt., MC, for the encephalographic studies described and to R. L. Patrick, MD, of the Laboratory for Experimental Biology, St. Louis, Missouri for histopathological studies. W-71003.

This report is designated as SysteMed Corporation Report No.

This technical report has been reviewed and approved.

CLINTON L. HOLT, Colonel, USAF, MC

Commander

Aerospace Medical Research Laboratory 
TABLE OF CONTENTS

$\underline{\text { Section }}$

$\underline{\text { Page }}$

I . INTRODUCTION

II MATERIALS AND METHODS 2

ANIMAL EXPOSURE FACILITIES

EXPERIMENTAL CONDITIONS 2

CONTAMINANT GENERATION AND MONITORING OF CHAMBER CONCENTRATIONS

III EXPERIMENTAL RESULTS 4

RESULTS OF RANGE-FINDING STUDIES 4

90-DAY CONTINUOUS EXPOSURES 6

$\begin{array}{ll}\text { Experimental Conditions } & 7\end{array}$

Clinical Tests on Dogs and Monkeys _ : $\quad \ldots \quad$. 7

$\begin{array}{ll}\text { Tests on Rats } & 7\end{array}$

RESULTS OF LARGE ANIMAL EXPOSURES

$\begin{array}{lr}\text { Clinical Measurements } & 8\end{array}$

$\begin{array}{ll}\text { Histopathology: } & 8\end{array}$

Dogs $\quad 8$

$\begin{array}{ll}\text { Monkeys } & 18\end{array}$

$\begin{array}{ll}\text { RESULTS OF RAT EXPOSURES } & 18\end{array}$

$\begin{array}{ll}\text { Growth ... } & 18\end{array}$

$\begin{array}{ll}\text { Organ Weight } & 18\end{array}$

Histopathology , 18

IV CONCLUSIONS $\quad 22$

REFERENCES 23 


\section{LIST OF TABLES}

Table

Page

I Effect of 2-Week Exposure to Inhaled Methylisobutylketone (100 ppm) on Organ Weights of Albino Rats

II Effect of 2-Week Exposure to Inhaled Methylisobutylketone $(200 \mathrm{ppm})$ on Organ Weights of Albino Rats

III Clinical Laboratory Results of MIBK Exposed and Control Dogs

IV Clinical Laboratory Results on MIBK Exposed and Control Monkeys

V Serum Acid Phosphatase Levels in Animals Continuously Exposed to $410 \mathrm{mg} / \mathrm{M}^{3}$ MIBK

VI Serum Glucuronidase Activity in Animals Continuously Exposed to $410 \mathrm{mg} / \mathrm{M}^{3}$ MIBK

VII Results of BSP Liver Function Tests on Animals Continuously Exposed to $410 \mathrm{mg} / \mathrm{M}^{3}$ MIBK for 90 Days

VIII Effect of 90-Day Continuous Exposure to MIBK on Organ and Organ to Body Weight Ratios in Albino Rats 


\section{SECTION I}

\section{INTRODUCTION}

Methylisobutylketone (MIBK) is used as a solvent in a plastic formulation which, in the pliable manufactured end product form, is relatively noncombustible in an oxygen-rich environment. This quality in the finished plastic product makes it a highly useful material for space cabin equipment such as seat padding.

The manufactured product contains, entrapped in the plastic, some residual MIBK which will outgas under reduced pressure conditions and may appear as a contaminant in the spacecraft environment.

Industrial experience with MIBK has not shown any adverse physiological effects on man other than headache or nausea at or around the industrial Threshold Limit Value (TLV) of $100 \mathrm{ppm}$. Elkins (reference 1) reported that exposed workers developed some tolerance to MIBK during the working week but lost this tolerance over the weekend. Silverman et al. (reference 2) found that a 100-ppm exposure to MIBK was acceptable to 12 human volunteers for a 15-minute period but that $200 \mathrm{ppm}$ was objectionable due to odor intensity. Because high air concentrations of MIBK have a narcotic action which would affect human performance, further information about prolonged or continuous exposure to this chemical was desired. Two-week range-finding experiments were conducted at $100 \mathrm{ppm}$ and $200 \mathrm{ppm}$ MIBK under continuous exposure conditions to establish criteria for a subsequent longer term study. This 90-day study was designed and performed to evaluate the continuous inhalation toxicity of MIBK under space cabin conditions. 


\section{SECTION II}

\section{MATERIALS AND METHODS}

\section{ANIMAL EXPOSURE FACILITIES}

Animal exposure facilities (references 3 and 4) of the Aerospace Medical Research Laboratory were used for both the 2-week and the 90-day continuous experiments. The altitude chambers (Thomas Domes) are capable of operating at pressures between 5 psia $(258 \mathrm{~mm} \mathrm{Hg})$ and 14.7 psia $(760 \mathrm{~mm} \mathrm{Hg})$. They are equipped to operate with either $100 \%$ oxygen, ambient air, or mixtures of these gases over a range of $20 \%$ to $100 \%$ oxygen in the atmosphere of the chamber. The chambers are automated to control temperatures at $72+5 \mathrm{~F}$ and relative humidity at $50+10 \%$. Gas flow through a chamber may be varied from 0 to 125 cfm. A flow rate of $40 \mathrm{cfm}$ maintains the carbon dioxide concentration below $0.5 \%$ (usual range of $0.05-0.10 \%$ ) when the chamber has a full load of animals.

\section{EXPERIMENTAL CONDITIONS}

The 2-week range-finding experiments were conducted in the altitude chambers operating in the ambient pressure mode. Air flow was maintained at $40 \mathrm{cfm}$ and chamber temperature at $72 \mathrm{~F}$. The absolute pressure was held at $725 \mathrm{~mm} \mathrm{Hg}$ to seal the chamber and prevent contamination of the surrounding laboratory environment with MIBK vapor. After completion of the 2-week studies a 90-day continuous exposure study was performed at $260 \mathrm{~mm} \mathrm{Hg}$ pressure, mixed-gas conditions. During the latter experiment, the gas flow was maintained at $40 \mathrm{cfm}$ and temperature was held in the $72+5 \mathrm{~F}$ range. The gas mixture used was $68 \% \mathrm{O}_{2}-32 \% \mathrm{~N}_{2}$ at 5 psia pressure.

\section{CONTAMINANT GENERATION AND MONITORING OF CHAMBER CONCENTRATIONS}

The MIBK used in these studies was purchased from the Matheson Company, Incorporated, East Rutherford, New Jersey. The liquid was introduced into an all glass vaporizing unit by means of a dual syringe pump from a large reservoir. Dry air flowing through the heated vaporizer carried the MIBK vapor through a flowmeter and metering valve system into the chamber air supply duct. The stainless steel tubing between the vaporizer and metering valve was heated to prevent recondensation of the MIBK. Heating was not necessary after dilution in the chamber air supply duct. 
A gas chromatographic procedure was developed for contaminant monitoring on a semi-continuous basis. Air samples were taken from a position in the chamber just above the breathing zone of the dogs and continuously pumped to the analyzer system where an automatic sampling valve took samples every 5 minutes. The samples were introduced directly into the gas chromatograph sample inlet.

The MIBK in the gas sample was separated on a 10-inch column of Porapak Q operated at $190 \mathrm{C}$ and detected with a flame ionization detector. The retention time of MIBK in this system was 1.5 minutes which allowed convenient sampling at 5 minute intervals. MIBK vapor calibration standards made up in Mylar ${ }^{\circledR}$ bags were used daily and a variation in detector response of $+5 \%$ was found. The variation from one bag to another when run the säme day was approximately $2 \%$. 


\section{RESULTS OF RANGE-FINDING STUDIES}

Rats, mice, dogs and monkeys were continuously exposed to a mean concentration of $100 \mathrm{ppm}$ MIBK for 2 weeks at ambient conditions in the Thomas Domes. Test animals included 4 monkeys, 8 dogs, 40 mice, and 50 rats. As controls, 3 monkeys, 4 dogs, 20 mice, and 25 rats were placed in another Thomas Dome under the same conditions with the exception of contaminant. One monkey in each group had cortical electrodes implanted for evaluation of central nervous system (CNS) effects.

Test programs were designed to evaluate the inhalation effects of the MIBK exposure as outlined below:

\section{Preexposure Tests}

1. Body Weight

2. Clinical Chemistry

3. Hematology

4. EEG

\section{During Exposure Tests}

1. Spontaneous Activity Measurement

2. Symptomatology

3. Mortality Response

\section{Postexposure Tests}

1. Body Weight

2. Organ to Body Weight Ratios

3. EEG

4. Clinical Chemistr.y

-5. Hematology

6. Pathology

7. Blood $\mathrm{pH}$ and Gases

There were no signs of toxic response during exposure. At the end of the 2-week exposure period there was no difference in cortical activity between the exposed and control monkey nor were any significant differences observed in hematologic or clinical chemistry measurements for either dogs or monkeys. Gross pathologic examination 
of tissues from both exposed and control animals failed to reveal any apparent differences. Blood gas measurements made on dogs did not show any effects attributable to MIBK exposure. Tissue specimens were collected at necropsy and examined microscopically.

Organ weight and organ to body weight ratios were evaluated and the kidneys found significantly heavier in the rats exposed to MIBK (see table I).

\section{TABLE I}

Effect of 2-Week Exposure to Inhaled Methylisobutylketone (100 ppm) on Organ Weights of Albino Rats

\section{EXPOSED}

\begin{tabular}{|c|c|c|c|c|c|}
\hline & Heart & Lung & Liver & Spleen & Kidneys \\
\hline $\mathrm{N}$ & 50 & 48 & 50 & 50 & 50 \\
\hline$\overline{\mathrm{x}}$ Organ Wt. ${ }^{1}$ & 1.0 & 1. 2 & 8.6 & 0.8 & 1. $7^{* *}$ \\
\hline$\overline{\mathrm{x}}$ Ratios 2 & 0.416 & 0.547 & 3.756 & 0.353 & $0.729 * *$ \\
\hline
\end{tabular}

\section{CONTROLS}

$\begin{array}{llllll}\mathrm{N} & 25 & 23 & 24 & 25 & 25\end{array}$

$\begin{array}{llllll}\overline{\mathrm{x}} \text { Organ Wt. }^{1} & 0.9 & 1.3 & 8.4 & 0.8 & 1.5 \\ \overline{\mathrm{x}} \text { Ratios }^{2} & 0.417 & 0.569 & 3.753 & 0.346 & 0.670\end{array}$

$\begin{array}{ll}1 & \text { grams } \\ 2 & \text { grams } / 100 \text { grams body weight }\end{array}$

** significantly different from controls at 0.01 level

Since the only preliminary indication of a toxic response to the 2 -week inhalation exposure of 100 ppm MIBK was its effect on rat kidney weight and a slight indication of depressed growth in rats, a second 2-week exposure was conducted at an atmospheric concentration of 200 ppm MIBK, and the same biological measurements and examinations were performed.

The animals exposed to $200 \mathrm{ppm}$ MIBK showed no outward toxic effects that could be attributed to the 2-week exposure. Again the only effect observed was on rats in which both the liver and kidney weights were statistically different from those in the control group as shown in table II. 
Effect of 2-Week Exposure to Inhaled Methylisobutylketone (200 ppm) on Organ Weights of Albino Rats

EXPOSED

\begin{tabular}{|c|c|c|c|c|c|}
\hline & Heart & Lung & Liver & Spleen & Kidneys \\
\hline $\mathrm{N}$ & 50 & 46 & 50 & 50 & 50 \\
\hline$\overline{\mathrm{x}}$ Organ Wt. ${ }^{1}$ & 0.9 & 1.3 & $9.0^{* *}$ & 0.8 & $1.8^{* *}$ \\
\hline $\bar{x}$ Ratios $^{2}$ & $0.357^{*}$ & 0.499 & 3. $445^{* *}$ & 0.291 & $0.694^{* *}$ \\
\hline
\end{tabular}

\section{CONTROLS}

$\begin{array}{llllll}\mathrm{N} & 50 & 42 & 50 & 50 & 50\end{array}$

$\begin{array}{llllll}\overline{\mathrm{x}} \text { Organ Wt. }{ }^{1} & 0.9 & 1.3 & 8.2 & 0.8 & 1.5 \\ \overline{\mathrm{x}} \text { Ratios }^{2} & 0.343 & 0.510 & 3.198 & 0.303 & 0.582\end{array}$
1 grams
2 grams/100 grams body weight
* significant at the 0.05 level only
** significant at the 0.01 level

From the data obtained in this experiment and observations made from the previous MIBK inhalation study, the kidney appeared to be the organ primarily affected by the exposure to MIBK. Physical properties of MIBK (bp $117 \mathrm{C}$ ) suggest that the kidney may be the major route of excretion. The persistent finding of significant changes in kidney weights and kidney to body weight ratios in the rat indicated that MIBK exposure caused kidney changes. Histopathologic examination of the rat kidney revealed toxic nephrosis in the proximal tubules of MIBK exposed rats at both exposure levels.

Based on these results the $100 \mathrm{ppm}$ MIBK exposure level was selected for the continuous 90 -day study under simulated space cabin conditions.

\section{0-DAY CONTINUOUS EXPOSURES}

The experimental animal species selected for prolonged continuous exposure included dogs, rats and monkeys. All animals used were males. The numbers of animals used in the test and control groups were as follows: 


$\begin{array}{lrl}\text { Albino Rats } & 100 \text { - Wistar Strain } \\ \text { Dogs } & 8 \text { - Beagle Variety } \\ \text { Monkeys } & 2 \text { - Macaca mulatta }\end{array}$

Two additional monkeys were placed in each group for special studies by other laboratories. These monkeys were surgically prepared with exteriorized kidneys for repetitive punch biopsy. The biopsy material was prepared for electron microscopic studies and submitted to the Albany Medical Center at the request of the National Aeronautics and Space Administration (NASA). The results of these examinations were not available when this report was prepared.

\section{Experimental Conditions}

The test animals were exposed to $410 \mathrm{mg} / \mathrm{M}^{3}$ MIBK vapor (100 millimole $/ 25 \mathrm{M}^{3}$ ) for a period of 90 days in an altitude chamber operated at 5 psia pressure and a $68 \% \mathrm{O}_{2}-32 \% \mathrm{~N}_{2}$ gas mixture. The control group of animals was maintained in a separate altitude chamber, under identical environmental conditions, except that no MIBK was present.

Clinical Tests of Dogs and Monkeys

All dogs were examined biweekly, including the month prior to initiation of the experiment. At the time of each examination, the dogs were weighed and blood samples were taken for hematology and a battery of clinical chemistry tests.

Liver function tests (bromsulphalein [BSP] dye retention) were performed preexposure and immediately postexposure. Serum acid phosphatase and serum glucuronide determinations were done preexposure and at 30 and 60 days.

At termination, two dogs from each group were transferred to the postexposure holding room for 60 days to determine reversibility of effects should any lesions be found. The remaining six dogs in each group were killed, examined grossly, and samples of liver, brain, kidney, heart, lung, spleen, and endocrine glands were taken for histological evaluation.

Tests on Rats

Rats were weighed preexposure and biweekly during the exposure period to determine growth rate. Two rats from each group were necropsied at weekly intervals for 3 weeks and then at biweekly intervals thereafter. After 2 weeks exposure, 10 rats were removed from each chamber and necropsied in groups of 2 at biweekly intervals to determine reversibility of the kidney lesion as seen in the preliminary experiments. At 
termination of the experiment, 10 rats from each group were removed and saved for serial sacrifice for reversibility studies, 10 were submitted to histopathology, and the remaining rats were necropsied and the visceral organs weighed for determination of organ to body weight ratios.

\section{RESULTS OF LARGE ANIMAL EXPOSURES}

\section{Clinical Measurements}

The results of clinical chemistry and hematology tests on dogs and monkeys did not reveal any biologically significant differences between the exposed animals and their controls. The biweekly mean values of these determinations are shown in table III for dogs and in table IV for monkeys.

Serum acid phosphatase levels determined on dogs and monkeys before exposure and at various intervals during exposure are shown in table V. Although some increase over baseline level was seen in the animals during exposure, the values were not different from those of control animals.

The results of serum glucuronidase activity measurements are shown in table VI. The difference between the exposed and control monkeys is relatively large but remains fairly constant throughout the experiment and is not related to the MIBK exposure.

Liver function tests were performed on dogs before and after 90-day exposure to MIBK. Bromsulphalein ( $4 \mathrm{mg} / \mathrm{kg}$ ) was given intravenously and the dye concentration measured in blood 15 minutes later. There were no significant differences between the exposed and control animals as shown in table VII.

Histopathology:

\section{$\underline{\text { Dogs }}$}

Tissue sections from heart, lung, brain, liver, spleen, kidney, adrenals and pituitary glands were examined in both exposed and control animals. No differences were observed between the two groups. Since the range-finding experiments had shown the kidney to be the target organ, the routine hematoxylin and eosin stained sections were supplemented with thin sections $(1 \mu)$ stained with toluidine blue, methylene blue and oil red-O. In the thin sections, hyaline droplets were noted in one exposed and in one control dog while the oil-red $O$ showed fat 
Clinical Laboratory Results on MIBK

Exposed and Control Dogs

\begin{tabular}{|c|c|c|c|c|c|c|}
\hline \multirow{2}{*}{$\begin{array}{l}\text { Weeks } \\
\text { Exposed }\end{array}$} & \multicolumn{2}{|c|}{$\begin{array}{c}\text { HCT } \\
\text { (vol \%) }\end{array}$} & \multicolumn{2}{|c|}{$\begin{array}{c}\text { HGB } \\
\text { (grams \%) }\end{array}$} & \multicolumn{2}{|c|}{$\begin{array}{c}\mathrm{RBC} \\
\text { (millions) }\end{array}$} \\
\hline & Exposed & Control & Exposed & Control & $\overline{\text { Exposed }}$ & Control \\
\hline-1 & 45 & 44 & 15.3 & 14.8 & 6.8 & 6.8 \\
\hline 1 & 43 & 46 & 14.6 & 14.9 & 6.4 & 6.5 \\
\hline 3 & 47 & 44 & 15.6 & 15.5 & 6.6 & 5.9 \\
\hline 5 & 44 & 43 & 15.2 & 14.9 & 6.7 & 6.5 \\
\hline 7 & 47 & 45 & 15.6 & 14.7 & 6.8 & 6.5 \\
\hline 9 & 47 & 48 & 15.5 & 16.0 & 5.3 & 7.1 \\
\hline 11 & 47 & 46 & 15.5 & 14.7 & 6.8 & 6.7 \\
\hline 13 & 47 & 47 & 15.4 & 15.4 & 5.7 & 5.8 \\
\hline
\end{tabular}

WBC

Weeks

Exposed

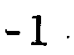

1

3

5

7

9

11

13

9.6

12.5 (thousands)

Sodium

(meg/liter)

Exposed Contro

148

146

149

146

145

147

150

151

146

151

148

13. 4

152
Potassium (meg/liter)

Exposed Control

4.7

4.5

4.5

4. 4

4. 8

4.5

4. 9

4. 4

4.8

4.5

4. 4

4. 4

13. 2 
TABLE III -- CONTINUED

\begin{tabular}{|c|c|c|c|c|c|c|}
\hline \multirow{2}{*}{$\begin{array}{c}\text { Weeks } \\
\text { Exposed }\end{array}$} & \multicolumn{2}{|c|}{$\begin{array}{c}\text { Cholesterol } \\
\text { (mg \%) }\end{array}$} & \multicolumn{2}{|c|}{$\begin{array}{l}\text { Calcium } \\
\text { (mg \%) }\end{array}$} & \multicolumn{2}{|c|}{$\begin{array}{c}\text { Total Phosphorus } \\
\text { (mg \%) }\end{array}$} \\
\hline & Exposed & Control & Exposed & Control & Exposed & Control \\
\hline-1 & 159 & 130 & 10.3 & 10.2 & 4.6 & 4.8 \\
\hline 1 & --- & -- & 10.5 & 10.3 & 4.8 & 4.6 \\
\hline 3 & 151 & 131 & 10.3 & 10.3 & 4.8 & 4.6 \\
\hline 5 & 153 & 144 & 10.6 & 10.2 & 4.8 & 5.3 \\
\hline 7 & 159 & 148 & 10.6 & 10.3 & 5.0 & 4.9 \\
\hline 9 & 153 & 151 & 10.5 & 10.4 & 4. 5 & 4.7 \\
\hline 11 & 149 & 154 & 10.5 & 10.3 & 3.9 & 4.5 \\
\hline 13 & 149 & 144 & 10.6 & 10.6 & 5.0 & 4.9 \\
\hline
\end{tabular}

\begin{tabular}{|c|c|c|c|c|c|c|}
\hline \multirow{2}{*}{$\begin{array}{c}\text { Weeks } \\
\text { Exposed }\end{array}$} & \multicolumn{2}{|c|}{$\begin{array}{l}\text { Total Bilirubin } \\
\text { (mg \%) }\end{array}$} & \multicolumn{2}{|c|}{$\begin{array}{c}\text { Albumin } \\
\text { (grams \%) }\end{array}$} & \multicolumn{2}{|c|}{$\begin{array}{l}\text { Total Protein } \\
\text { (grams \%) }\end{array}$} \\
\hline & Exposed & Control & Exposed & Control & Exposed & Control \\
\hline-1 & 0.2 & 0.3 & 3.6 & 3.6 & 5.8 & 5.9 \\
\hline 1 & 0.2 & 0.2 & 3.6 & 3.8 & 6.1 & 6.4 \\
\hline 3 & 0.3 & 0.3 & 3.5 & 3.4 & 6.2 & 6.1 \\
\hline 5 & 0.2 & 0.2 & 3.6 & 3.6 & 6.2 & 6.2 \\
\hline 7 & 0.2 & 0.2 & 3.6 & 3.7 & 6.2 & 6.2 \\
\hline 9 & 0.2 & 0.2 & 3.6 & 3.7 & 6.3 & 6.4 \\
\hline 11 & 0.3 & 0.3 & 3.7 & 3.8 & 6.3 & 6.3 \\
\hline 13 & 0.1 & 0.1 & 3.8 & 3.6 & 6. 3 & 6.4 \\
\hline
\end{tabular}


TABLE III -- CONCLUDED

\begin{tabular}{|c|c|c|c|c|c|c|}
\hline \multirow{2}{*}{$\begin{array}{c}\text { Weeks } \\
\text { Exposed }\end{array}$} & \multicolumn{2}{|c|}{ (mg \%) } & \multicolumn{2}{|c|}{ (mg $\%)$} & \multicolumn{2}{|c|}{$(\mathrm{mg} \%)$} \\
\hline & Exposed & Control & Exposed & Control & $\overline{\text { Exposed }}$ & Control \\
\hline-1 & 0.7 & 0.6 & 13 & 13 & 103 & 104 \\
\hline 1 & 0.7 & 0.6 & 14 & 12 & 86 & 91 \\
\hline 3 & 0.6 & 0.7 & 12 & 12 & 96 & 96. \\
\hline 5 & 0.5 & 0.5 & 13 & 13 & 104 & 101 \\
\hline 7 & 0.6 & 0.6 & 12 & 14 & 102 & 106 \\
\hline 9 & 0.4 & 0.4 & 11 & 14 & 101 & 114 \\
\hline 11 & 0.5 & 0.6 & 13 & 13 & 101 & 101 \\
\hline 13 & 0.4 & 0.4 & 10 & 12 & 98 & 108 \\
\hline
\end{tabular}

\begin{tabular}{|c|c|c|c|c|c|c|}
\hline \multirow{2}{*}{$\begin{array}{c}\text { Weeks } \\
\text { Exposed }\end{array}$} & \multicolumn{2}{|c|}{$\begin{array}{c}\text { Alkaline Phosphatase } \\
\text { (KA units) }\end{array}$} & \multicolumn{2}{|c|}{$\begin{array}{l}\text { Creatinine } \\
(\mathrm{mg} \mathrm{\%})\end{array}$} & \multicolumn{2}{|c|}{$\begin{array}{c}\text { Chloride } \\
\text { (meq/liter) }\end{array}$} \\
\hline & Exposed & Control & Exposed & Control & Exposed & Control \\
\hline-1 & 22 & 14 & 0.8 & 0.8 & 115 & 114 \\
\hline 1 & 22 & 19 & 0.6 & 0.7 & 115 & 115 \\
\hline 3 & 13 & 14 & 0.6 & 0.6 & 116 & 112 \\
\hline 5 & 13 & 12 & 0.7 & 0.6 & 114 & 114 \\
\hline 7 & 10 & 10 & 0.7 & 0.8 & 112 & 112 \\
\hline 9 & 10 & 10 & 0.6 & 0.7 & 118 & 117 \\
\hline 11 & 11 & 11 & 0.7 & 0.7 & 117 & 116 \\
\hline 13 & 11 & 12 & 0.6 & 0.6 & 116 & 112 \\
\hline
\end{tabular}




\section{Clinical Laboratory Results on MIBK}

Exposed and Control Monkeys

\begin{tabular}{|c|c|c|c|c|c|c|}
\hline \multirow{2}{*}{$\begin{array}{c}\text { Weeks } \\
\text { Exposed } \\
\end{array}$} & \multicolumn{2}{|c|}{$\begin{array}{l}\text { HCT } \\
\text { (vol \%) }\end{array}$} & \multicolumn{2}{|c|}{$\begin{array}{c}\text { HGB } \\
\text { (grams \%) }\end{array}$} & \multicolumn{2}{|c|}{$\begin{array}{c}\mathrm{RBC} \\
\text { (millions) }\end{array}$} \\
\hline & Exposed & Control & Exposed & Control & Exposed & Control \\
\hline-1 & 39 & 37 & 12.1 & 12.2 & 5.4 & 5.4 \\
\hline 1 & 40 & 41 & 12.0 & 12.2 & 5.4 & 5.4 \\
\hline 3 & 40 & 36 & 12.3 & 12.5 & 5.2 & 5.4 \\
\hline 5 & 35 & 39 & 11.4 & 12.1 & 5.0 & 5.3 \\
\hline 7 & 38 & 38 & 11.8 & 11.9 & 4.9 & 5.4 \\
\hline 9 & 36 & 38 & 11.4 & 12.3 & 4.7 & 5.3 \\
\hline 11 & 36 & 39 & 11.3 & 11.4 & 4.9 & 5.4 \\
\hline 13 & 37 & 40 & 11.1 & 12.0 & 4.8 & 5.0 \\
\hline
\end{tabular}

WBC

Weeks

Exposed

$-1$

1

3

5

7

9

11

13 (thousands) Exposed Control

9.4

8.6

5.2

4.8

4.8

5. 4

5.1

5.1

5. 3

6.7

5.6

147

155

151

148

153

149

150

152
Sodium $\frac{(\mathrm{meq} / \text { liter })}{\text { Exposed }} \frac{\text { (meq/liter) }}{\text { Control Exposed Control }}$
151

154

151

Potassium

(mea/liter)

4. 3

3.9

4. 2

4. 6

151

4.5

4. 1

146

4. 3

4. 1

148

5. 1

4.5

4.5

4.5

4.6

3.8

4. 8

4.4 
TABLE IV -- CONTINUED

\begin{tabular}{|c|c|c|c|c|c|c|}
\hline \multirow{2}{*}{$\begin{array}{l}\text { Weeks } \\
\text { Exposed }\end{array}$} & \multicolumn{2}{|c|}{$\begin{array}{c}\text { Cholesterol } \\
\text { (mg \%) }\end{array}$} & \multicolumn{2}{|c|}{$\begin{array}{l}\text { Calcium } \\
\text { (mg \%) }\end{array}$} & \multicolumn{2}{|c|}{$\begin{array}{l}\text { Total Phosphorus } \\
\text { (mg \%) }\end{array}$} \\
\hline & Exposed & Control & Exposed & Control & $\overline{\text { Exposed }}$ & Control \\
\hline-1 & 198 & 168 & 10.9 & 10.8 & 5.9 & 4.2 \\
\hline 1 & -- & -- & 10.8 & 11.0 & 7.6 & 7.5 \\
\hline 3 & 225 & 188 & 10.4 & 10.6 & 8.1 & 6.8 \\
\hline 5 & 210 & 205 & 10. 2 & 10.6 & 7.7 & 7.4 \\
\hline 7 & 198 & 188 & 10.6 & 10.4 & 8.4 & 8.0 \\
\hline 9 & 218 & 195 & 10.2 & 10.8 & 7.4 & 6.4 \\
\hline 11 & 188 & 215 & 10. 2 & 10.6 & 6.1 & 7.6 \\
\hline 13 & 208 & 188 & 10.8 & 10.7 & 7.0 & 6.0 \\
\hline
\end{tabular}

\begin{tabular}{|c|c|c|c|c|c|c|}
\hline \multirow{2}{*}{$\begin{array}{c}\text { Weeks } \\
\text { Exposed }\end{array}$} & \multicolumn{2}{|c|}{$\begin{array}{c}\text { Total Bilirubin } \\
(\mathrm{mg} \%)\end{array}$} & \multicolumn{2}{|c|}{$\begin{array}{l}\text { Albumin } \\
\text { (grams \%) }\end{array}$} & \multicolumn{2}{|c|}{$\begin{array}{l}\text { Total Protein } \\
\quad(\text { grams \%) }\end{array}$} \\
\hline & Exposed & Control & Exposed & Control & Exposed & Control \\
\hline-1 & 0.2 & 0.2 & 4.7 & 4.7 & 7.9 & 7.6 \\
\hline 1 & 0.3 & 0.4 & 5.1 & 5.1 & 8.1 & 7.9 \\
\hline 3 & 0.3 & 0.4 & 5.0 & 5.1 & 8.1 & 7.9 \\
\hline 5 & 0.4 & 0.3 & 4.7 & 5.1 & 7.8 & 7.8 \\
\hline 7 & 0.3 & 0.4 & 4.8 & 5.0 & 7.7 & 7.6 \\
\hline 9 & 0.3 & 0.4 & 5.1 & 5.0 & 7.8 & 7.7 \\
\hline 11 & 0.3 & 0.4 & 5. 1 & 5.2 & 7.5 & 7.7 \\
\hline 13 & 0.1 & 0.1 & 5.3 & 5.0 & 8.0 & 7.7 \\
\hline
\end{tabular}


TABLE IV -- CONCLUDED

\begin{tabular}{|c|c|c|c|c|c|c|}
\hline \multirow{2}{*}{$\begin{array}{c}\text { Weeks } \\
\text { Exposed } \\
\end{array}$} & \multicolumn{2}{|c|}{$\begin{array}{l}\text { Uric Acid } \\
(\mathrm{mg} \%)\end{array}$} & \multicolumn{2}{|c|}{$\begin{array}{c}\text { BUN } \\
(\mathrm{mg} \%)\end{array}$} & \multicolumn{2}{|c|}{$\begin{array}{r}\text { Glucose } \\
(\mathrm{mg} \%)\end{array}$} \\
\hline & Exposed & Control & Exposed & Control & Exposed & Control \\
\hline-1 & 0.5 & 0.5 & 22 & 18 & 90 & 98 \\
\hline 1 & 0.6 & 0.5 & 15 & 17 & 85 & 65 \\
\hline 3 & 0.6 & 0.5 & 17 & 18 & 93 & 80 \\
\hline 5 & 0.4 & 0.5 & 20 & 17 & 95 & 80 \\
\hline 7 & 0.5 & 0.4 & 18 & 22 & 80 & 75 \\
\hline 9 & 0.3 & 0.4 & 18 & 14 & 85 & 83 \\
\hline 11 & 0.3 & 0.4 & 18 & 22 & 70 & 78 \\
\hline 13 & 0.4 & 0.3 & 16 & 13 & 78 & 88 \\
\hline
\end{tabular}

Alkaline Phosphatase Creatinine Chloride

Weeks

Exposed

$-1$

1

3

5

7

9

11

13 (KA units) Exposed Control

64

47

50

44

45

49

45

48

45

47

51 (mg \%)

Exposed Control

1. 2

1.3

0.9

1. 1

0.9

1. 0

1. 4

1. 3

1.2

1. 1

1.1

1.2

0.9

1.0

1. 2
115 (meq/liter)

115

113

112

111

108

114

Exposed Control

116

110

112

110

110

116

111

111 


\section{TABLE V}

Serum Acid Phosphatase Levels* in Animals Continuously Exposed to $410 \mathrm{mg} / \mathrm{M}^{3}$ MIBK

DOGS

Baseline $\quad 30$ Days 60 Days

Controls (8)

Total

Prostatic

Residual
$5.4(3.1-8.2)$

$2.1(1.3-2.7)$

$3.4(1.8-5.5)$
$5.0(3.8-6.5)$

$2.2(1.4-3.2)$

$2.9(2.0-3.8)$
$5.8(4.2-8.3)$

$2.3(1.9-3.1)$

$3.4(1.6-5.3)$

Exposed (8)

Total

Prostatic

Residual
$4.4(3.6-5.1)$

$1.9(1 . \breve{-2}-2.3)$

$2.5(1.8-3.1)$
$5.3(3.7-9.0)$

$2.2(1.7-3.0)$

$3.2(1.4-6.6)$
$5.3(4.1-6.9)$

$2.3(1.8-3.0)$

$2.9(2.0-4.5)$

MONKEYS

Controls (2)

Total

Prostatic

Residual
$20.8(20.5,21.2)$

$5.5(5.4,5.6)$

$15.3(14.9,15.8)$
$20.9(19.2,22.7)$

$5.5(3.9,7.2)$

15. $4(15.3,15.5)$
$20.2(19.5,21.0)$

$5.3(5.0,5.7)$

$15.0(14.5,15.3)$

Exposed (2)

Total

$16.1(15.6,16.6)$

$19.4(17.8,21.0)$

$4.4(3.7,5.2)$

$5.5(5.4,5.7)$

$19.6(16.2,23.0)$

Prostatic

$11.7(11.4,11.9)$

$13.8(12.4,25.3)$

5. 6. $(5.3,5.9)$

Residual

*The enzyme activity is measured in International Units (uM p-nitrophenol formed per minute per liter serum @ 37 C, pH 4.8). 


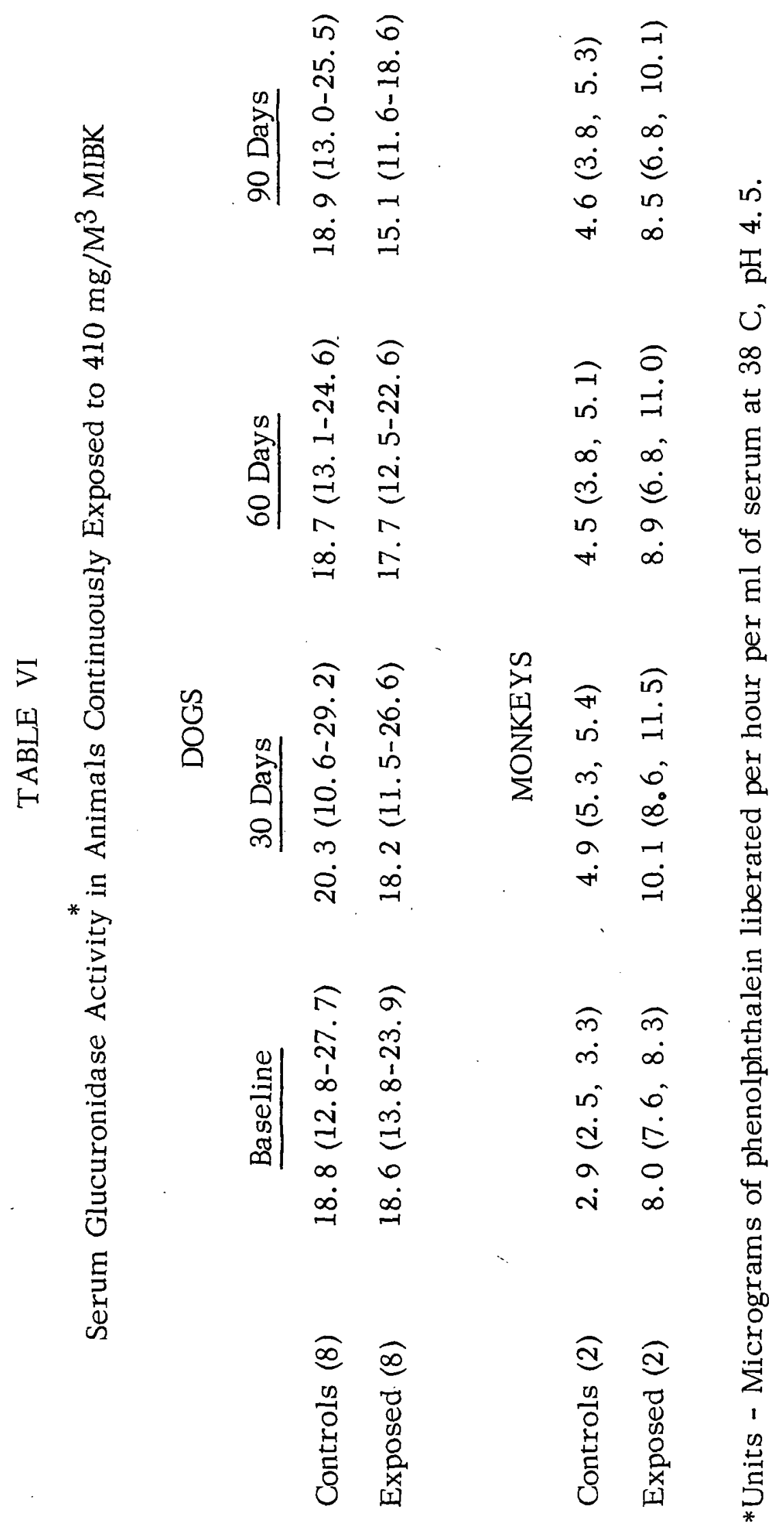


TABLE VII

Results of BSP Liver Function Tests on Animals Continuously

Exposed to $410 \mathrm{mg} / \mathrm{M}^{3} \mathrm{MIBK}$ for 90 Days

Control Dog Number

M-48

M-64

N-10

$\mathrm{M}-76$

N-08

N-06

$M-42$

$\mathrm{M}-14$
Percent Dye Retention

$\underline{0 \text { Day }}$

6.5

4.5

8.0

8.0

9.0

5.0

5.5

10.0

8.5

0.5

8.0

10.0

8.5

5.5

10. 0

11.5

\section{Exposed Dog Number}

N-14

M-66

M-70

M-44

M-26

M-34

M-30

M-32
11.0

8. 0

7.0

11.0

8.0

7.0

7.5

8.5
11.0

7.5

7. 0

12.5

3. 2

6.0

7.0

8. 0 . 
scattered in a few tubules at the corticomedullary junction in exposed dogs. The latter finding is commonly seen in untreated dogs. The methylene blue stains showed no differences between the exposed and control animals.

\section{Monkeys}

The two monkeys in each group without translocated kidneys were examined histologically. The same tissues as examined in dogs were screened with $\mathrm{H}$ and $\mathrm{E}$ stains. One of the two exposed monkeys exhibited focal chronic inflammation of the kidney. No other pathological changes were noted.

\section{RESULTS OF RAT EXPOSURES}

Growth

The growth rates (measured biweekly) of both the exposed and control groups of rats are shown in figure 1. There was no significant effect upon the growth rate as a result of continuous exposure to MIBK for 90 days.

Organ Weight

The effect of exposure to MIBK on albino rat organ weights and organ to body weight ratios is shown in table VIII. There is a statistically significant difference in the liver and kidney weights of the exposed animals with a corresponding increase in organ to body weight ratios for these tissues.

Histopathology

No significant pathologic changes were seen in any of the organs examined from control rats. All exposed rats, however, showed hyaline droplet degeneration of the proximal tubules with occasional foci of tubular necrosis upon completion of the 90-day exposure to $410 \mathrm{mg} \mathrm{MIBK} / \mathrm{M}^{3}$. Rats removed from exposure after 15, 22, 28, 71 and 85 days also showed the same changes in kidney tubules. Thus, as few as 15 days of exposure to the experimental condition produced some pathologic change in kidney tissue. A trend toward a linear progression of hyaline droplet degeneration over the time period of exposure was observed, although individual animals did not all follow this pattern. Also of note, hyaline droplets tended to be larger with time, possibly as a result of coalescence of the smaller droplets. 
Growth Rate of Albino Rats Continuously

Exposed to MIBK for 90 Days

\section{$500-$}

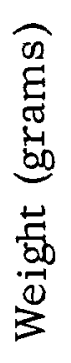

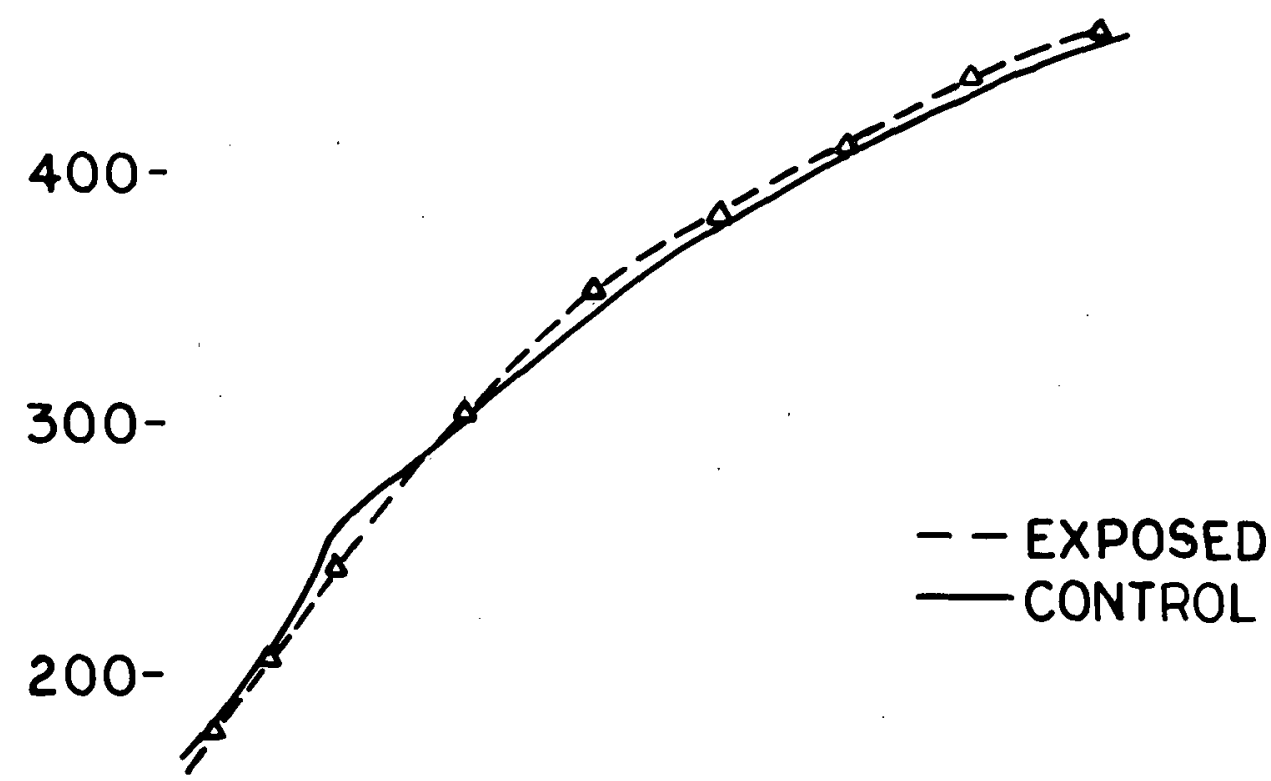

$100-$

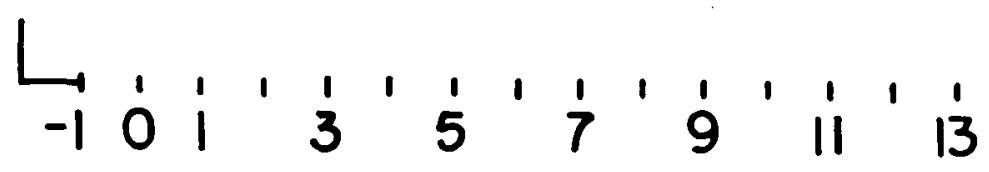

Weeks Exposed 


\section{TABLE VIII}

Effect of 90-Day Continuous Exposure to MIBK on Organ and Organ to Body Weight Ratios in Albino Rats

$\frac{\begin{array}{c}\text { Organ Weight } \\ \text { (grams) }\end{array}}{\text { Test }} \quad \frac{\text { Control }}{\mathrm{N}=56}$

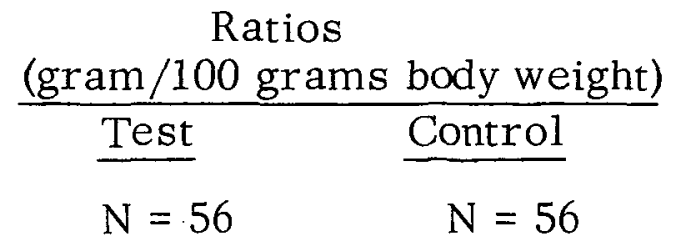

Heart

1.3

1.3

0.302

0.306

Lung

1.5

1.5

0.352

0.359

Liver

10. $8^{* *}$

9. 9

2. $477^{* *}$

2. 305

Spleen

0.7

0.7

0.159

0. 160

Kidney

3. $1^{* *}$

2. 6

$0.713 * *$

0.604

** significant at the 0.01 level 
Although rat liver weights and liver to body weight ratios showed a statistically significant increase in exposed animals, there were no pathologic changes associated with this increase.

Rats removed for reversibility studies after 15-day exposure to MIBK revealed a gradual reversion of kidney tubular damage with time which appeared to be completely reversed in those rats held for 60 days postexposure. The rats retained and serially killed for reversibility studies after 90-day exposure also exhibited recovery from the MIBK induced lesion but not as rapidly as those exposed for a shorter period. 


\section{SECTION IV}

\section{CONCLUSIONS}

Animals exposed continuously to $410 \mathrm{mg} / \mathrm{M}^{3}$ MIBK for 90 days under space cabin environmental conditions were not adversely affected, with the exception of albino rats. Hyaline droplet tubular nephrosis developed in albino rats under the experimental conditions used but did not result in debilitation or death. The lesions developed within 2 weeks of exposure and were reversible upon removal from the MIBK environment even after 90-day exposure. Based on the results of these experiments in space cabin environments, concentrations of MIBK up to 410 $\mathrm{mg} / \mathrm{M}^{3}$ (100 ppm equivalent) should be tolerable for man for the time period investigated. Furthermore, these data indicate that the 60minute emergency limit of $100 \mathrm{ppm}$ and the $90-$ and 1000-day provisional limit of $20 \mathrm{ppm}$ as established by the Space Science Board, NAS/NRC, in 1968 contain a wide margin of safety. 


\section{REFERENCES}

1. Elkins, H. B., The Chemistry of Industrial Toxicology, 2nd ed. Wiley, New York, 1959.

2. Silverman, L., H. Schulte and M. First, "Further Studies on Sensory Response to Certain Industrial Solvent Vapors, " J. Ind. Hyg. Toxicol. , 28, 262, 1946.

3. MacEwen, J. D., Toxic Hazards Research Unit Design and Construction Phase, AMRL-TR-65-125, Aerospace Medical Research Laboratory, Wright-Patterson AFB, Ohio, September, 1965, AD 624473.

4. Thomas, A. A., "Low Ambient Pressure Environments and Toxicity," A. M. A. Arch. Environ. Health, 11, 316, 1968. 